\title{
Performance of Conventional and Transgenic Soybean Cultivars in the South and Alto Paranaiba Regions of Minas Gerais, Brazil
}

\author{
Isabela Pereira de Lima, Adriano Teodoro Bruzi*, Flávia Barbosa Silva Botelho, \\ Everton Vinicius Zambiazzi, Igor Oliveri Soares, Alan Mario Zuffo
}

Department of Agriculture, Federal University of Lavras (UFLA), Lavras, Brazil

Email: *adrianobruzi@dag.ufla.br

Received 26 April 2015; accepted 8 June 2015; published 11 June 2015

Copyright (C) 2015 by authors and Scientific Research Publishing Inc.

This work is licensed under the Creative Commons Attribution International License (CC BY).

http://creativecommons.org/licenses/by/4.0/

\section{(c) (i) Open Access}

\begin{abstract}
The aim of this study was to compare transgenic and conventional soybean cultivars in regard to yield performance and agronomic traits. Six soybean cultivars were tested: three conventional cultivars and their three isogenic transgenic derivatives, in two locations, Lavras and Patos de Minas in Minas Gerais, Brazil, in the 2012/13 crop season. Data on yield (kg.ha-1), plant height (cm), and tolerance to lodging were collected. The cultivars had different responses. The cultivar BRS/MG46 Conquista had lower yields than its isogenic derivative BRS Valiosa RR, but this was not seen with the conventional cultivar M-SOY 6101, which produced more than its isogenic derivative M-SOY 7211 RR. Between the isogenic cultivars BRS/MG68 Vencedora and BRS Favorita RR, there were no significant differences. Nevertheless, the contrast between the mean values of the transgenic and conventional cultivars shows that the conventional cultivars had mean values greater than the transgenic cultivars.
\end{abstract}

\section{Keywords}

Evaluation, Glycine max L. Merrill, Isogenic Lines, Transgenic Crops

\section{Introduction}

Soybean (Glycine max L.) is an oilseed crop of great economic importance. The high protein and oil contents in ${ }^{*}$ Corresponding author.

How to cite this paper: Lima, I.P.de, Bruzi, A.T., Botelho, F.B.S., Zambiazzi, E.V., Soares, I.O. and Zuffo, A.M. (2015) Performance of Conventional and Transgenic Soybean Cultivars in the South and Alto Paranaiba Regions of Minas Gerais, Brazil. American Journal of Plant Sciences, 6, 1385-1390. http://dx.doi.org/10.4236/ajps.2015.69138 
the seeds/grain have made it one of the main nutrient sources for animals and humans. Due to its strategic function, this leguminous plant has become a highly traded commodity on the international market and is now an important alternative for income for farmers throughout the world.

In Brazil, soybean growing has become one of the most expressive economic activities in domestic agriculture. It is currently the most grown crop in the country and is one of the main sources of foreign currency in agribusiness and for the Brazilian commercial trade balance as a whole. Brazil is the second largest producer of the grain, with production of around 90 thousand tons [1].

Soybean growing in Brazil has followed the rise of a series of technological innovations throughout its history that over time have been refined and incorporated in the productive process. In the 1990s, Brazilian producers witnessed the expansion of transgenic soybean cultivars in the USA and Argentina. Already at the end of this period, the technology began to be tested in Brazil, sparking interest in Brazilian farmers through the ease of growing transgenic soybean compared to conventional soybean. Although transgenic soybean that is resistant to glyphosate herbicide has been grown in Brazil since the end of the 1990s, it was legalized only in 2005. As of that time, transgenic events have come to be incorporated in Brazilian cultivars.

Throughout the period of development of transgenic technology, some reports have arisen questioning the yield efficiency of these transgenic cultivars when compared to conventional cultivars. Since then, studies have been carried out to compare these two types of crops, transgenic and conventional, and it is possible to find various results with different conclusions on the matter in the literature [2]-[6].

Glyphosate herbicide-resistant soybean is currently grown on most commercial soybean cropland in Brazil [7]. Transgenic crops were one of the technologies most rapidly adopted in agriculture and, currently, in addition to resistance to herbicide, use of the recombinant DNA technique clears the way for the creation of multiple possibilities of transgenic events. Within this scenario, comparative studies between transgenic and conventional soybean cultivars become important [8].

In light of the above, the aim of this study was to compare transgenic and conventional soybean cultivars in regard to yield performance and agronomic traits in the region of Lavras and Patos de Minas, Minas Gerais, Brazil.

\section{Material and Methods}

In the 2012/13 crop year, experiments were conducted in two locations, the South and Alto Paranaíba regions of Minas Gerais, with one experiment on the EPAMIG experimental farm in Patos de Minas, located at $1074 \mathrm{~m}$ altitude, $18^{\circ} 29^{\prime} 70^{\prime \prime}$ latitude south and $46^{\circ} 26^{\prime} 55^{\prime \prime}$ longitude west; and the other in the experimental area of the Crop and Livestock Scientific and Technological Development Center (Muquém Farm), Lavras, MG, Brazil, located at an altitude of $954 \mathrm{~m}, 21^{\circ} 12^{\prime} 11^{\prime \prime}$ latitude south and $44^{\circ} 58^{\prime} 47^{\prime \prime}$ longitude west.

The results of soil chemical analyses before setting up the experiment resulted in the following values for Lavras: $\mathrm{pH}\left(\mathrm{H}_{2} \mathrm{O}\right)$ 5.9, $\mathrm{P}\left(\mathrm{mg} \cdot \mathrm{dm}^{-3}\right) 7.21, \mathrm{~K}\left(\mathrm{mg} \cdot \mathrm{dm}^{-3}\right) 118, \mathrm{Ca}\left(\mathrm{cmol}^{-3} \mathrm{dm}^{-3}\right) 4.7, \mathrm{Mg}\left(\mathrm{cmol}^{-3} \mathrm{dm}^{-3}\right) 1.3, \mathrm{Al}$ $\left(\mathrm{cmol} \cdot \mathrm{dm}^{-3}\right)$ 0.0, $\mathrm{H}+\mathrm{Al}\left(\mathrm{cmol} \cdot \mathrm{dm}^{-3}\right)$ 2.0, SB $\left(\mathrm{cmol}^{-1} \mathrm{dm}^{-3}\right) 6.3, \mathrm{~T}\left(\mathrm{cmol} \cdot \mathrm{dm}^{-3}\right) 6.3, \mathrm{t}\left(\mathrm{cmol}^{-3} \mathrm{dm}^{-3}\right)$ 9.2, $\mathrm{V}(\%)$ 68.51, M (\%) 0.0, MO (dag $\left.\cdot \mathrm{Kg}^{-1}\right)$ 2.61, Prem $\left(\mathrm{mg}^{-\mathrm{L}^{-1}}\right)$ 13.33, $\mathrm{Zn}\left(\mathrm{mg} \cdot \mathrm{dm}^{-3}\right)$ 5.31, Mn $\left(\mathrm{mg} \mathrm{dm}^{-3}\right)$ 13.33, Cu (mg $\left.\mathrm{dm}^{-3}\right)$ 0.60, B $\left(\mathrm{mg} \cdot \mathrm{dm}^{-3}\right)$ 0.33; and for Patos de Minas: $\mathrm{pH}\left(\mathrm{H}_{2} \mathrm{O}\right)$ 5.88, $\mathrm{P}\left(\mathrm{mg}^{-3} \mathrm{dm}^{-3}\right) 46.99, \mathrm{~K}\left(\mathrm{mg} \cdot \mathrm{dm}^{-3}\right)$ 80.0, Ca $\left(\mathrm{cmol} \cdot \mathrm{dm}^{-3}\right)$ 1.55, $\mathrm{Mg}\left(\mathrm{cmol} \cdot \mathrm{dm}^{-3}\right)$ 0.87, $\mathrm{Al}\left(\mathrm{cmol} \cdot \mathrm{dm}^{-3}\right) 0.04, \mathrm{H}+\mathrm{Al}\left(\mathrm{cmol}^{-3} \mathrm{dm}^{-3}\right) 3.66, \mathrm{SB}\left(\mathrm{cmol} \cdot \mathrm{dm}^{-3}\right) 2.62, \mathrm{~T}$ $\left(\mathrm{cmol} \cdot \mathrm{dm}^{-3}\right)$ 2.66, t $\left(\mathrm{cmol} \cdot \mathrm{dm}^{-3}\right.$ 6.28, V (\%) 41.78, M (\%) 1.5, MO (dag $\left.\mathrm{Kg}^{-1}\right)$ 2.68, Prem $\left(\mathrm{mg} \cdot \mathrm{L}^{-1}\right)$ 4.82, Zn $\left(\mathrm{mg} \cdot \mathrm{dm}^{-3}\right) 3.5, \mathrm{Fe}\left(\mathrm{mg} \cdot \mathrm{dm}^{-3}\right) 38.1, \mathrm{Mn}\left(\mathrm{mg} \cdot \mathrm{dm}^{-3}\right) 76.4, \mathrm{Cu}\left(\mathrm{mg} \cdot \mathrm{dm}^{-3}\right) 14.8, \mathrm{~B}\left(\mathrm{mg} \cdot \mathrm{dm}^{-3}\right)$ 0.17, and S $\left(\mathrm{mg} \cdot \mathrm{dm}^{-3}\right)$ 8.09. The climatic data are shown in Figure 1.

Three conventional soybean cultivars were evaluated-M-SOY 6101 (Monsanto), BRS/MG 46 Conquista (EMBRAPA), and BRS/MG 68 Vencedora (EMBRAPA), and their transgenic versions-M-SOY 7211 RR (Monsanto), BRS Valiosa RR (EMBRAPA), and BRS Favorita RR (EMBRAPA) in each environment.

Soybeans were planted in the first half of November 2012 in a no-tillage area and inoculation was performed on the plant furrow with liquid inoculant soon after planting. Fertilization followed the recommendations of the Soil Fertility Commission of the State of Minas Gerais [9] and was carried out in the planting furrow with 400 $\mathrm{kg} \cdot \mathrm{ha}^{-1}$ of the commercial formula 2-30-20. Twenty-five days after germination, the plants were thinned, leaving 12 plants per linear meter. The other crop treatments were carried out in a uniform manner in the experimental area according to the procedure indicated by [10].

The experimental plots consisted of two five-meter rows at a spacing of $50 \mathrm{~cm}$ between rows, making up a 

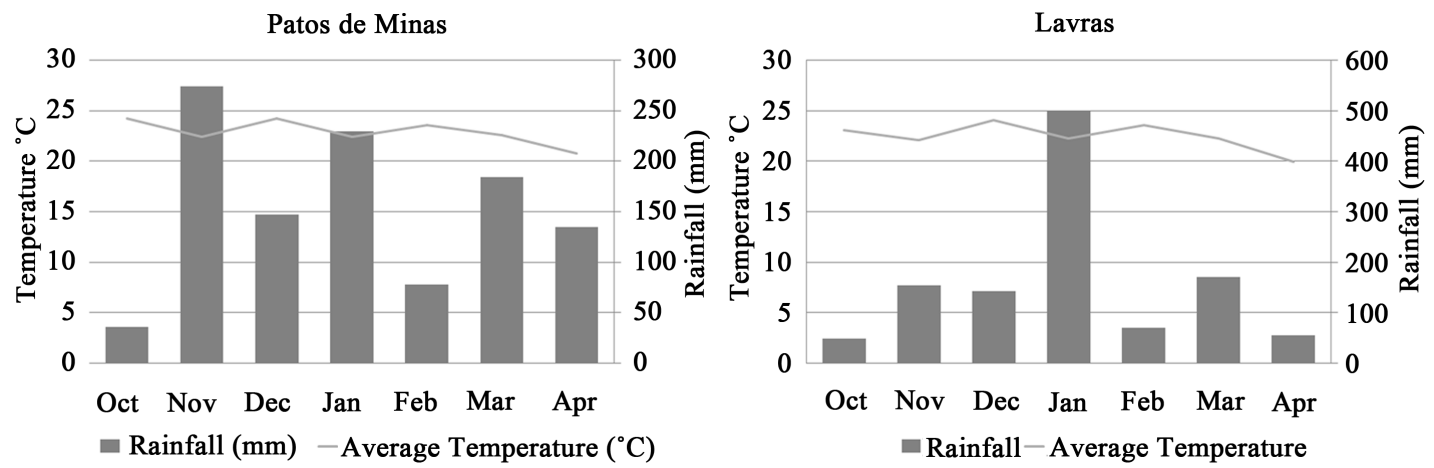

Figure 1. Monthly variations of rainfall and temperature in the period from October to April in experiments conducted in the municipalities evaluated.

total area of $5.0 \mathrm{~m}^{2}$ per plot, with outside boundary strips. A randomized block experimental design was used, with three replications in two locations.

Performance of the cultivars was evaluated in regard to grain yield $\left(\mathrm{kg} \cdot \mathrm{ha}^{-1}\right)$ at $13 \%$ moisture, plant height $(\mathrm{cm})$, and the lodging score, which was obtained according to [11], adopting the following scoring scale: 1 for all plants upright, 2 for some plants bending over or slight lodging, 3 for all the plants moderately bending over or $25 \%$ - 50\% lodging, 4 for all the plants severely bent over or $50 \%$ - $80 \%$ lodging, and 5 for plants with more than $80 \%$ lodging.

The results obtained were subjected to combined analysis of variance per location and the mean values were compared by the Scott-Knott test at 5\% probability. Statistical analysis was made with the assistance of the SISVAR statistical package [12]. Experimental precision was evaluated by the accuracy estimate [13] using the following estimator (Equation (1)):

$$
r=\sqrt[2]{1-\frac{1}{F_{c}}} \times 100
$$

In which:

$r$ accuracy expressed in percentage;

$F_{c} F$ calculated value.

Contrasts between the conventional and transgenic cultivars were also estimated so as to characterize differences between the mean values of the traits evaluated. The confidence interval test between the two mean values was used for this analysis through the SISVAR statistical package [12].

\section{Results and Discussion}

From the summary of analysis of variance (Table 1$)$ a significant difference $(\mathrm{p} \leq 0.05)$ was observed for all the traits evaluated-grain yield, plant height, and lodging score. Only the location factor did not show a significant difference for yield.

The accuracy estimates reflect the precision of the experiments carried out and also the existence of variability. According to [14], accuracy estimates greater than $70 \%$ are considered to be of high magnitude, which was observed for all the traits evaluated, showing the high precision of the experiments.

The mean values for yield showed variation between the three pairs of isogenic cultivars studied, with the greatest difference found between the cultivars M-SOY 6101, with a mean yield of $2988.23 \mathrm{~kg} \cdot \mathrm{ha}^{-1}$, and its isogenic counterpart M-SOY $7211 \mathrm{RR}$, with a mean yield of $2265.36 \mathrm{~kg} \cdot \mathrm{ha}^{-1}$, where the conventional cultivar had $31.9 \%$ greater yield, just as found by some other authors [3] [15]. As for the isogenic cultivars BRS/MG 46 Conquista and BRS Valiosa RR, the mean values varied from $2244.00 \mathrm{~kg} \cdot \mathrm{ha}^{-1}$ to $2885.43 \mathrm{~kg} \cdot \mathrm{ha}^{-1}$ (Table 2), with the transgenic cultivar standing out, with $28.5 \%$ greater yield than the conventional cultivar. The third pair of cultivars studied, BRS/MG68 Vencedora and BRS Favorita RR, did not show a significant difference, just as shown by [6] in the state of Parana, Brazil

The estimated contrasts (Table 2), comparing the overall mean values of the conventional and transgenic cultivars, show that in this study, the conventional cultivars had greater mean yields when compared to the mean 
Table 1. Summary of analysis of variance for the traits evaluated-grain yield $\left(\mathrm{kg}^{\mathrm{h}} \mathrm{ha}^{-1}\right)$, plant height ( $\left.\mathrm{cm}\right)$, and lodging. UFLA, Lavras, 2013.

\begin{tabular}{ccccc}
\hline SV & DF & \multicolumn{3}{c}{ Mean Square } \\
\cline { 3 - 5 } & & Yield $\left(\mathrm{kg} \cdot \mathrm{ha}^{-1}\right)$ & Height $(\mathrm{cm})$ & Lodging \\
\hline Cultivars & 5 & $616096.16^{*}$ & $165.10^{*}$ & $0.84^{*}$ \\
Location & 1 & 42435.31 & $12992.20^{*}$ & $5.44^{*}$ \\
Cult. $\times$ Location & 5 & $738206.47^{*}$ & $72.95^{*}$ & $0.84^{*}$ \\
Replications & 4 & 1034140.76 & 27.44 & 0.03 \\
Error & 20 & 135836.27 & 14.30 & 0.13 \\
Accuracy (\%) & & 88.29 & 95.57 & 92.12 \\
\hline
\end{tabular}

*Significant at 95\% confidence level by F-test.

Table 2. Phenotypic mean values of the traits—grain yield $\left(\mathrm{kg} \cdot \mathrm{ha}^{-1}\right)$, plant height $(\mathrm{cm})$, and lodging score obtained in the trial for comparison of conventional and transgenic cultivars in Lavras and Patos de Minas, MG, Brazil. UFLA, Lavras, MG, 2013.

\begin{tabular}{cccc}
\hline Cultivars & Yield $\left(\mathrm{kg} \cdot \mathrm{ha}^{-1}\right)$ & Lodging & Plant Height (cm) \\
\hline BRS/MG68 Vencedora & $2826.52 \mathrm{a}$ & $2.00 \mathrm{a}$ & $73.80 \mathrm{c}$ \\
BRS Favorita RR & $2672.36 \mathrm{a}$ & $1.00 \mathrm{c}$ & $69.11 \mathrm{~d}$ \\
M-SOY 6101 & $2988.23 \mathrm{a}$ & $1.33 \mathrm{c}$ & $74.23 \mathrm{a}$ \\
M-SOY 7211 RR & $2265.36 \mathrm{~b}$ & $1.00 \mathrm{c}$ b & $73.90 \mathrm{c}$ \\
BRS/MG46 Conquista & $2244.99 \mathrm{~b}$ & $1.50 \mathrm{~b}$ & $74.10 \mathrm{c}$ \\
BRS Valiosa RR & $2885.43 \mathrm{a}$ & $1.50 \mathrm{~b}$ & 73.38 \\
& Mean values & 1.36 & 77.31 \\
Overall & 2647.15 & 1.61 & 74.13 \\
Conventional & 2686.58 & 1.17 & $3.18^{*}$ \\
Transgenic & 2607.72 & & $0.44^{*}$ \\
\hline
\end{tabular}

Means followed by the same letter belong to the same group according to Scott-Knott test at 95\% confidence level. *'Significant by the mean comparison test at $5 \%$ probability.

yields of the transgenic cultivars.

For the plant height trait, in contrast with the result found by [3], the conventional cultivars exhibited greater mean values, which were confirmed by the contrast (Table 2). Among the pairs of isogenic cultivars, there was no significant difference only for the cultivars BRS/MG46 Conquista and BRS Valiosa RR. For the other pairs of cultivars, the conventional cultivar exhibited height superior to the transgenic version. According to [16], the ideal height for mechanized harvest ranges from 60 to $120 \mathrm{~cm}$; thus, the cultivars evaluated exhibit an ideal mean value.

The lodging score, a trait which is directly related to plant height, varied according to height, with the conventional cultivars having the highest scores, representing a greater degree of lodging, since they also exhibited plant height greater than the transgenic cultivars. However, all the cultivars exhibited a lodging score within the ideal range, without hindering mechanized harvest.

The different cultivars showed variation for the traits evaluated. The estimated contrasts clearly show the significant difference between the mean values of the conventional and transgenic cultivars (Table 2). For all the 
traits evaluated, the contrasts show that the conventional cultivars had mean values greater than the transgenic cultivars.

The superiority of conventional cultivars in the traits of yield and plant height may be explained by the fact of introduction of an exotic gene in the transgenic cultivar, which makes the plant able to produce new substances and tolerate the herbicide, according to [5]. This change in the genome may cause different behavior in the transgenic plant compared to the conventional isogenic counterpart.

In Brazil, it may be seen that the greatest argument for adoption of transgenic soybean is reduction in the cost of production, with around $85 \%$ lower cost on herbicides compared to the conventional system. In contrast, among the arguments against transgenics, the low yield of transgenic soybean in relation to its conventional version is mentioned [17].

\section{Conclusion}

The cultivars exhibited differential response. The cultivar BRS/MG46 Conquista exhibited lower yields than its isogenic derivative BRS Valiosa RR, but this was not seen with the conventional cultivar M-SOY 6101, which produced more than its isogenic derivative M-SOY 7211 RR. Between the isogenic cultivars BRS/MG68 Vencedora and BRS Favorita RR, there were no significant differences.

\section{Acknowledgements}

The authorsexpresstheirthankstothe CNPq (Conselho Nacional de Desenvolvimento Científico e Tecnoló-gico), Capes (Coordenação de aperfeiçoamento de pessoal de nível superior), FAPEMIG (Fundação de amparo à pesquisa do Estado de Minas Gerais) for granting a doctoralandmastersscholarship. To EMPRAPA/SOJA (Empresa Brasileira de Pesquisa Agropecuária) and UFLA (Universidade Federal de Lavras) and FAPEMIG (Fundação de amparo à pesquisa do Estado de Minas Gerais) for the financial andlogisticsupport.

\section{References}

[1] Companhia Nacional de Abastecimento (2014) Acompanhamento da safra brasileira de grãos, v. 1—Safra 2013/14, n. 7-Sétimo Levantamento.

[2] Duffy, M. (2001) Who Benefits from Biotechnology? Paper Presented at American Seed Trade Association Meeting, Chicago, 5-7 December 2001.

[3] Elmore, R.W., Roeth, F.W., Klein, R.N., Knezevic, S.Z., Martin, A., Nelson, L.A., et al. (2001) Glyphosate-Resistance Soybean Cultivar Response to Glyphosate. Agronomy Journal, 93, 404-407. http://dx.doi.org/10.2134/agronj2001.932404x

[4] Pelaez, V., Albergoni, L. and Gerra, M.P. (2004) Soja transgênica versus soja convencional: uma análise comparativa de custos e benefícios. Cadernos de Ciência \& Tecnologia, 21, 279-309.

[5] Menegatti, A.L.A. and Barros, A.L.M. (2007) Análise comparativa dos custos de produção entre soja transgênica e convencional: Um estudo de caso para o Estado do Mato Grosso do Sul. Revista de Economia e Sociologia Rural, 45, 163-183. http://dx.doi.org/10.1590/S0103-20032007000100008

[6] Lima, W.F., Pípolo, A.E., Moreira, J.U.V., Carvalho, C.G.P., Prete, C.E.C., Arias, C.A.A., et al. (2008) Interação genótipoambiente de soja convencional e transgênica resistente a glifosato, no Estado do Paraná. Pesquisa Agropecuária Brasileira, 43, 729-736. http://dx.doi.org/10.1590/S0100-204X2008000600009

[7] Rocher, J. (2010) Brasil Transgênico. Jornal Gazeta do Povo.—Curitiba: Gazeta do Povo. http://www.gazetadopovo.com.br/caminhosdocampo/conteudo.phtml?tl=1\&id=1077231\&tit=Brasil-transgenico

[8] Galli, A.J.B. and Montezuma, M.C. (2005) Alguns aspectos da utilização do herbicida glyphosate na agricultura. http://www.monsanto.com.br/roundup/glyphosate/capitulo3/capitulo3 2.asp

[9] Ribeiro, A.C., Guimarães, P.T.G. and Alvarez, V.H. (1999) Comissão de Fertilidade do Solo do Estado de Minas Gerais - CFSEMG. Recomendação para o uso de corretivos e fertilizantes em Minas Gerais: 5a Aproximação. Viçosa, MG, Embrapa/UFV/SBCS, Cap. 5, 25-32.

[10] Carvalho, E.R., Rezende P.M.D., Ogoshi F.G.A., Botrel É.P., Alcantara H.P. and Santos J.P. (2010) Desempenho de cultivares de soja [Glycine max (L.) Merrill] em cultivo de verão no Sul de Minas Gerais. Ciência e Agrotecnologia, 34, 892-899. http://dx.doi.org/10.1590/S1413-70542010000400014

[11] Bernard, R.L., Chamberlain, D.W. and Lawrece, R.D. (1965) Results of the Cooperative Uniform Soybean Tests. USDA, Washington DC. 
[12] Ferreira, D.F. (2011) Sisvar: A Computer Statistical Analysis System. Ciência e agrotecnologia, 35, 1039-1042.

[13] Ramalho, M.A.O., Ferreira, D.F. and Oliveira, A.C. (2012) Experimentação em genética e melhoramento de plantas. 3rd Edition, UFLA, Lavras, 382 p.

[14] Resende, M.D.V. and Duarte, J.B. (2007) Precisão e controle de qualidade em experimentos de avaliação de cultivares. Pesquisa Agropecuária Tropical, 37, 182-194.

[15] Gordon, B. (2005) Manganese deficiency in Roundup ready soybeans: Agronomy e updates. Kansas State University, Manhattan, $1 \mathrm{p}$.

[16] Resende, P.M. and Carvalho, E.A. (2007) Avaliação de cultivares de Soja [Glycine max (L.) Merill] para o Sul de Minas Gerais. Ciência Agrotecnologia, 31, 1616-1623. http://dx.doi.org/10.1590/s1413-70542007000600003

[17] Silveira, J.V.F. and Resende, L.M. (2010) Estratégias de mercado no agronegócio paranaense: Soja convencional vs. transgênica. Produção, 20, 54-65. http://dx.doi.org/10.1590/s0103-65132010005000005 